\title{
Urban heat island analysis using the 'local climate zone' scheme in Presidente Prudente, Brazil ${ }^{1}$
}

\author{
Análisis de la isla de calor urbano utilizando el sistema \\ de 'zona climática local' en Presidente Prudente, Brasil
}

\author{
Renata dos Santos Cardoso ${ }^{2}$ \\ Margarete Cristiane de Costa Trindade Amorim ${ }^{3}$
}

\begin{abstract}
Although urban heat islands (UHIs) have been widely studied, a recent climate-based classification of urban and rural landscapes provides a new framework for UHI researchers. Based on the Local Climate Zone (LCZ) system, we studied heat islands in a tropical city, analysing the effects of urban morphology and surface cover on UHI intensity. Mobile measurements were taken in Presidente Prudente, São Paulo, Brazil, on five winter evenings (June and July 2014). Observed temperatures across the city show compact built zones with higher temperatures, followed by open midsize, lightweight low-rise, and low plants zones. A maximum nocturnal temperature difference of more than $5^{\circ} \mathrm{C}$ was detected between areas with significant differences in physical characteristics $\left(\Delta T_{\text {LCZ 24-D }}\right)$, whereas average inter-zone thermal differences reached $3.8^{\circ} \mathrm{C}\left(\Delta T_{\text {LCZ 3-D }}\right)$.
\end{abstract}

Keywords: Urban climate; urban heat island intensity; mobile traverses; tropical city.

\section{Resumen}

Aunque las islas de calor urbano (ICU) han sido ampliamente estudiadas, una reciente clasificación climática de los paisajes urbanos y rurales proporciona un nuevo marco para los investigadores de las ICU. Con base en el sistema de Zona Climática Local (LCZ), hemos investigado las islas de calor en una ciudad tropical, analizando los efectos de la morfología urbana y de los usos del suelo sobre la intensidad de la ICU. Las mediciones se han realizado en Presidente Prudente, São Paulo, Brasil, durante cinco noches de invierno (junio y julio de 2014). Las temperaturas observadas han mostrado zonas construidas compactas con temperaturas más altas, seguidas de zonas abiertas de media elevación, compacta poco consolidada de baja elevación y zonas de matorral. Se ha detectado una diferencia de temperatura nocturna máxima de más de $5^{\circ} \mathrm{C}$ entre las zonas con grandes contrastes en sus características físicas $\left(\Delta T_{\text {LCZ 24-D }}\right)$, mientras que las diferencias medias entre las zonas alcanzaron los $3,8^{\circ} \mathrm{C}\left(\Delta T_{\text {LCZ 3-D }}\right)$.

Palabras clave: Clima urbano; intensidad de la isla de calor urbano; medidas móviles; ciudad tropical.

\section{Introduction}

Climate studies in tropical regions are relatively recent, although urban climate research has grown considerably over the past decades. In Brazil, Monteiro (1976) wrote a pioneering work proposing a theoretical frame of reference (Urban Climate System) based on a systemic analysis and space-time in-

\footnotetext{
1 The paper is based upon research supported by the São Paulo Research Foundation (FAPESP) under Grant No. 2013/02057-0.

2 Department of Geography, São Paulo State University (UNESP), Presidente Prudente, São Paulo, Brazil. renatacardosol6@gmail.com

3 Department of Geography, São Paulo State University (UNESP), Presidente Prudente, São Paulo, Brazil. $\underline{\text { mccta@fct.unesp.br }}$
} 
terrelations. In this method, the urban climate is defined as "a system that encompasses the climate of a given terrestrial space and its urbanization" (Monteiro, 1976, p. 95).

In the Brazilian scenario, we can also highlight studies conducted by Tarifa (1977), Lombardo (1985), Mendonça (1994), Pitton (1997), Collischonn (1998), Amorim (2000, 2017), Sant'Anna Neto (2002), Dumke (2007), Ugeda Junior (2012), Alexandre (2013), Ortiz Porangaba (2015), among others. These studies sought to analyze and explain the origins and effects of urban climate phenomena, and propose prevention or mitigation strategies. As the studies reveal, the way human beings inhabit cities is evidence that environment conditions have been increasingly modified to adapt to human intentions. Furthermore, population growth without adequate urban planning that prioritizes social and environmental aspects has negatively affected the urban thermal climate and inhabitant health.

To understand the effects of urbanization on the urban canopy layer, Oke (2004) pointed out characteristics that need to be assessed, such as urban structure, surface cover, urban fabric, and urban metabolism. The combination of such factors modifies local energy and water balances, creating climate conditions that differ from surrounding rural areas and forming urban heat islands (UHI) (Oke, 1987; Arnfield, 2003; Hinkel, Nelson, Klene \& Bell, 2003; Voogt, 2004; Grimmond, 2007).

Therefore, to advance urban climate studies, especially those regarding UHIs, it is fundamental to consider detailed information on the differences of sites and land cover to support understanding of the climate derived from different spatial arrangements instead of taking the city as a whole. According to Mendonça (2003), the basis for intraurban climate differentiation consists of "the cartographic base and geographic knowledge of the city, and its sectorization or division into parts with relatively homogeneous characteristics." (p. 99).

Based on that, the purpose of this study was to analyze the UHI phenomenon during a winter period in Presidente Prudente, São Paulo, Brazil, classifying its different landscape patterns. The city has a great heterogeneity of landscapes in a small area, built surfaces with different thermal properties, reduced vegetation cover, and a high anthropogenic heat flux that has been associated with heat islands with intensities of up to $10^{\circ} \mathrm{C}$ (Amorim, Dubreuil \& Cardoso, 2015; Cardoso, 2015).

Among the classification systems found in the urban climate literature (Chandler, 1965; Auer, 1978; Ellefsen, 1990; Oke, 2004), we opted for Local Climate Zones (LCZ) by Stewart (2011). LCZ was developed as a classification system aimed at standardizing heat island studies in all cities and was the first climate-based classification of urban and rural landscapes for heat island researchers (Stewart, 2011). Zone names are quantifiable and not specific to time, culture, or location, and each zone represents an area that is local in scale and unique in land cover, building morphology, and thermal climate.

The landscape is represented by $17 \mathrm{LCZs}$, and the zones are named and ordered by one or more surface property. In most cases, this refers to the height and arrangement of the roughness of objects. Thus, this new classification leads to a more significant interpretation of UHI intensity through the temperature differences between LCZs $\left(\Delta T_{\text {LCZ X-Y }}\right)$ (Stewart, 2011; Stewart \& Oke, 2012).

Using local climate zones to map the landscape offers an improvement over the traditional "urbanrural" classification, and it has already been applied in different countries: Collischonn \& Mattos (2011) in Pelotas, Rio Grande do Sul, Brazil; Betchel, et al. (2012) in Hamburg, Germany; Puliafito, Bochaca, Allende \& Fernandez (2013) in Mendoza, Argentina; Lelovics, Gál \& Unger (2013) in Szeged, Hungary; Alexander \& Mills (2014) in Dublin, Ireland; Middel, Häb, Brazel, Martin \& Guhathakurta (2014) in Phoenix, Arizona, United States; Leconte, Bouyer, Claverie \& Pétrissans (2015) in Nancy, France.

Besides that, Stewart (2011) emphasized the need to carry out further research with this classification system in other cities, regions, and climates, especially in tropical cities, where data from case studies can contribute to improved design and the geographical characteristics of the system. By proposing more detailed knowledge of different intraurban thermal environments, this preliminary study identified temperatures increasing gradually from vegetated and open zones to compact built ones.

\subsection{Study area}

Presidente Prudente is a medium-sized city in the western region of São Paulo State, Brazil (figure 1), at $470 \mathrm{~m}$ above mean sea level. The city has an estimated population at 223,749, most of whom are living within the urban area, which corresponds to approximately $60 \mathrm{~km}^{2}$ (Brazilian Institute of Geography and Statistics (IBGE), 2016). 
Since the establishment of the city in 1917, there has been population growth and a consequent increase in land sales. During the 1920s and 1930s, Presidente Prudente was characterized by coffee and cotton production, which eventually contributed to the urbanization of the city due to the installation of cotton processing industries (Abreu, 1972).

From the 1950s to the 1970s, the oldest neighborhoods were built, and they currently correspond to densely built areas with scattered trees. By the 1980s and 1990s, residential areas with spaced buildings and vegetation cover were built, extending west of the old core. However, toward the western periphery, most residential areas are characterized by low-income housing. Due to the city's current expansion, this pattern also extends to the northern areas, where houses are built with materials that are not appropriate for the region's climate and thermal comfort (i.e., thin walls and roofs with asbestos-cement sheets or ceramic tile).

Figure 1. Location map of the study area

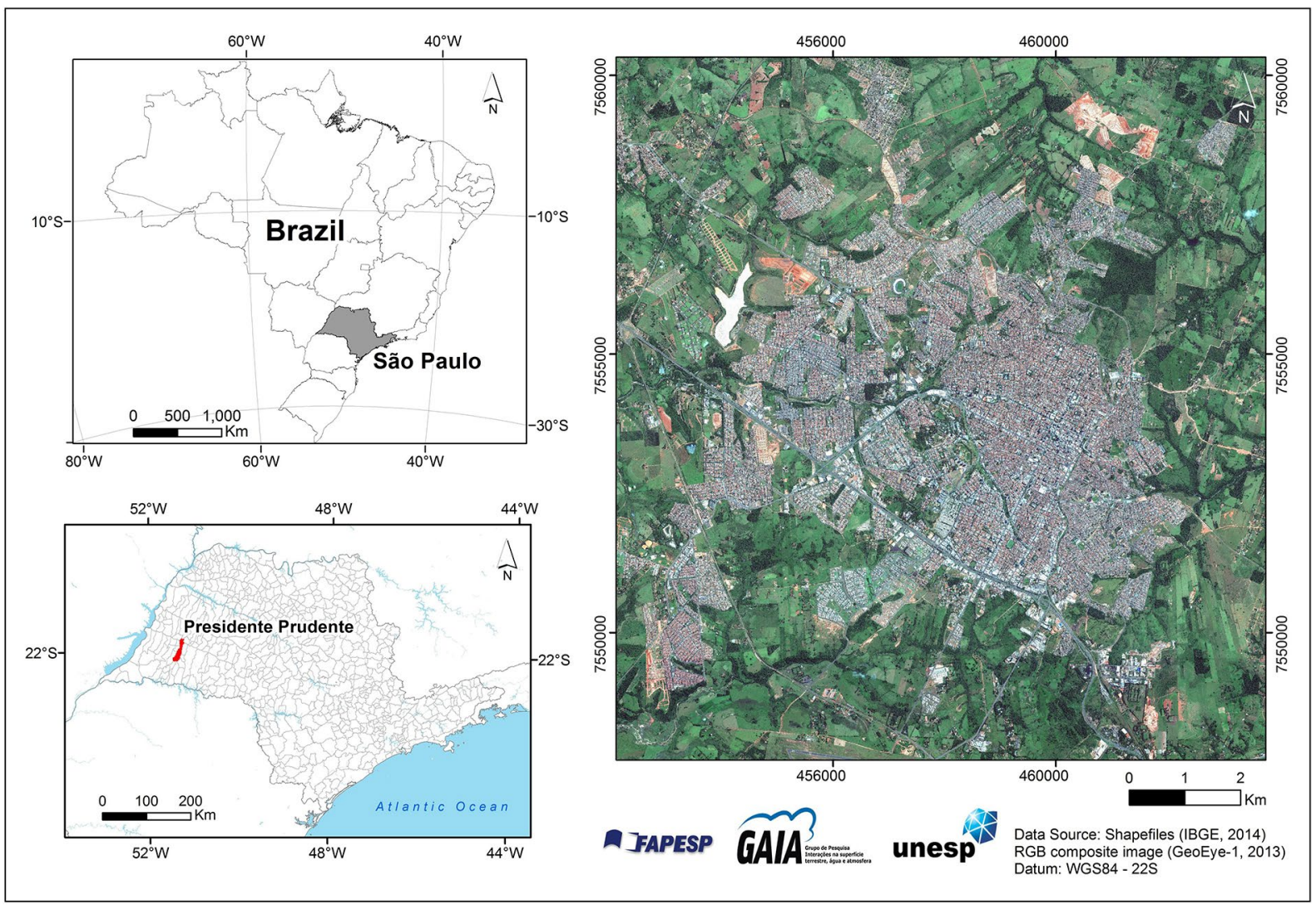

Source: Shapefiles from IBGE (2014); RGB image from GeoEye-1 (2013). Own elaboration.

The city's region is under a tropical climate regime, affected by the Atlantic Tropical mass (aTm), Continental Tropical mass (cTm), Continental Equatorial mass (cEm), and Atlantic Polar mass (aPm), among other atmospheric systems. Tropical systems give the city high temperatures during the spring and summer, whereas extratropical systems in the autumn and winter cause relatively low temperatures (Barrios \& Sant'Anna Neto, 1996).

Figure 2 shows average maximum air temperatures up to $28^{\circ} \mathrm{C}$ typically occurring from October to March, whereas minimum temperatures below $21^{\circ} \mathrm{C}$ occur from April to September. Throughout these months, precipitation ranges from $115 \mathrm{~mm}$ to $207 \mathrm{~mm}$, with December and January being the rainiest months. On the other hand, the season from June to August can be characterized as the driest in Presidente Prudente, with an average rainfall of $60 \mathrm{~mm}$.

In general, the climatic seasonality of the city can be summed up as a warm and rainy season from October to March and a milder and drier one from April to September, when temperatures decrease with the advance of polar masses. 
Figure 2. Climograph of Presidente Prudente

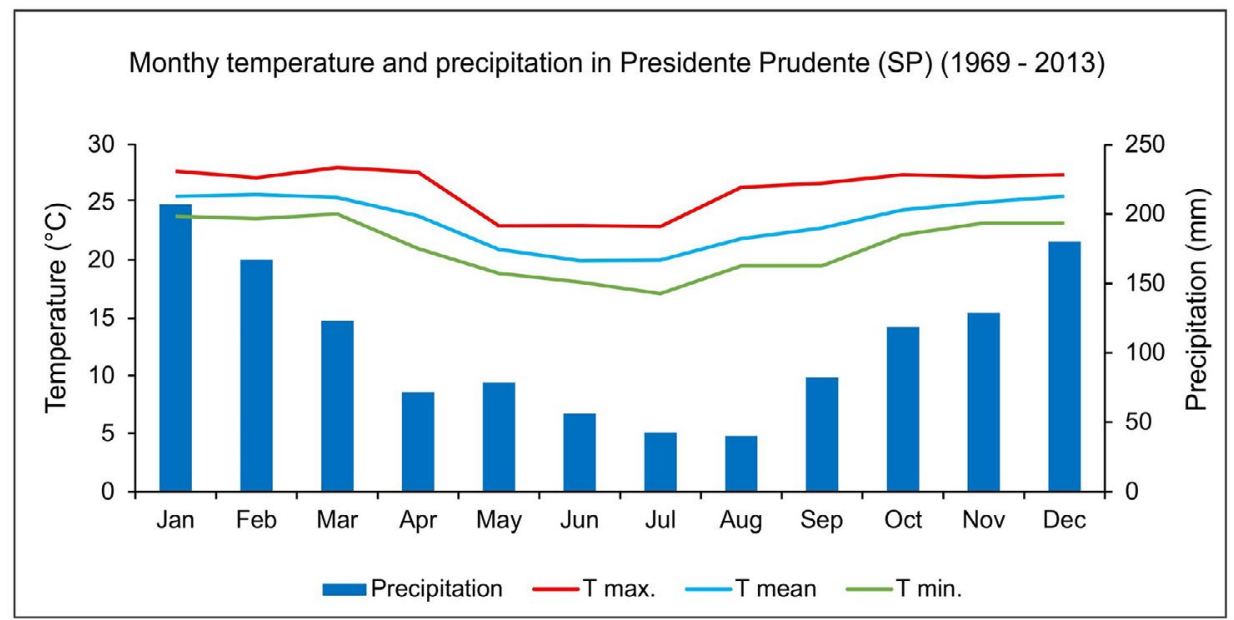

Source: National Institute of Meteorology, Meteorological Station of the School of Sciences and Technology - São Paulo State University (UNESP). Own elaboration.

\section{Methodology}

To investigate the urban heat island in Presidente Prudente, we first classified different landscape arrangements based on the Local Climate Zone (LCZ) system. Mobile traverses were then conducted to gather temperatures from different routes and calculate UHI intensity, defined as $\Delta T_{\text {LCZ X-Y. }}$

The LCZ application in Presidente Prudente draws upon a study by Cardoso (2015), in which potential local climate zones were mapped using urban blocks to define thermal source areas (figure 3).

Figure 3. Potential local climate zones in Presidente Prudente

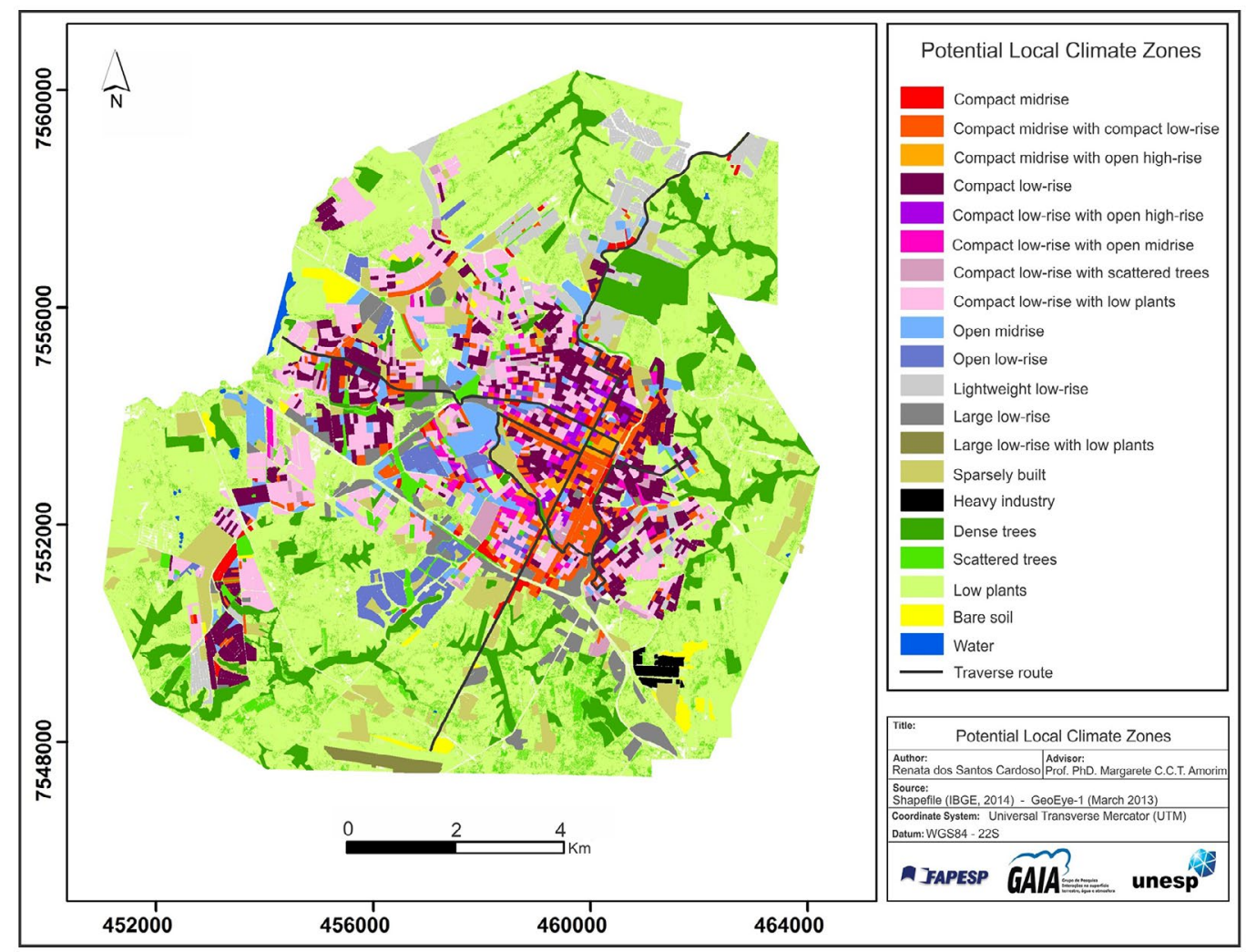

Source: Cardoso (2015). Own elaboration. 
To assess the UHI, we conducted mobile surveys after sunset during five winter evenings in June and July 2014 to gather temperatures from two traverse routes. We measured temperatures using digital thermohygrometers (model 7664.01.0.00; precision of $\pm 0.1^{\circ} \mathrm{C}$ ), fixed on a 1.5-meter-long wooden rod attached to the side of the vehicles.

Before beginning each route, enough time was given to allow the sensors to respond to outdoor exposure. We used two cars with a maximum speed of $30 \mathrm{~km} \mathrm{~h}^{-1}$ to cover the routes in approximately $1 \mathrm{~h}$. The west-east route was $18.3 \mathrm{~km}$ long and the south-north was $14.8 \mathrm{~km}$. We measured a total of 275 points and the average distance between points was approximately $100 \mathrm{~m}$ (figure 4).

\section{Figure 4. Traverses across the city}

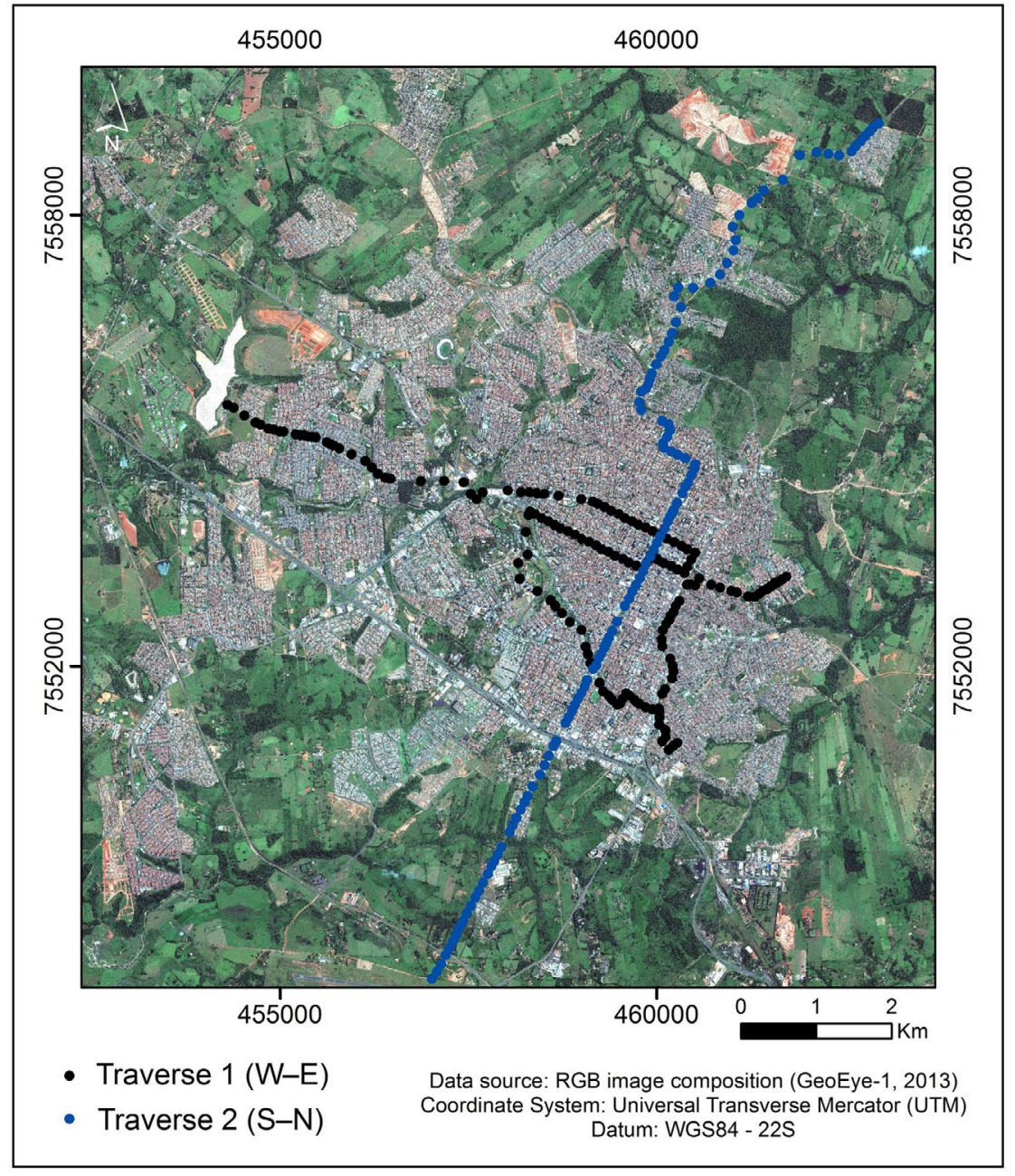

Source: GeoEye-1 (2013). Own elaboration.

We compared mobile measurements with data from the São Paulo State University (UNESP) meteorological station to verify if there was a significant change in temperature over one hour. However, since the differences ranged from $0^{\circ} \mathrm{C}$ to $0.6^{\circ} \mathrm{C}$, time-temperature corrections were not performed on the data.

The preliminary analyses presented in Section 3 are based on measurements made a few hours after sunset ( 9 p.m.), on evenings with clear sky, light winds $\left(<3 \mathrm{~m} \mathrm{~s}^{-1}\right)$, and no precipitation. Under the influence of the Atlantic Polar mass (aPm), a high-pressure system that causes atmospheric stability, observed temperature differences between urban and rural sites ranged from $6.3^{\circ} \mathrm{C}$ to $10.4^{\circ} \mathrm{C}$ (table 1 ).

We designed the routes to pass through a variety of surface morphology and land cover types across the study area. However, because of the complex mix of arrangements within the urban area, we selected five relatively homogeneous areas that correspond to the following LCZs: compact midrise with open high-rise, compact low-rise, open midrise, lightweight low-rise, and low plants. 
Table 1. Temperature differences $\left(\Delta T_{u-r}\right)$ and atmospheric systems during nighttime traverses in Presidente Prudente, June-July 2014

\begin{tabular}{ccccc}
\hline Date & $\boldsymbol{\Delta} \boldsymbol{T}_{\boldsymbol{u}-\boldsymbol{r}}\left({ }^{\circ} \mathbf{C}\right)$ & $\begin{array}{c}\text { Wind Speed } \\
\left(\mathbf{m ~ s}^{-1}\right)\end{array}$ & $\begin{array}{c}\text { Wind } \\
\text { Direction }\end{array}$ & Atmospheric Systems \\
\hline 30 June 2014 & 9.1 & 0.1 & SE & Atlantic polar mass (aPm) \\
1 July 2014 & 6.3 & 2.5 & SE & Atlantic polar mass (aPm) \\
2 July 2014 & 10.4 & 0 & - & Atlantic polar mass (aPm) \\
3 July 2014 & 7.4 & 1.4 & SE & Atlantic polar mass (aPm) \\
5 July 2014 & 9.7 & 1.4 & NE & Atlantic polar mass (aPm) \\
\hline
\end{tabular}

Source: Cardoso (2015). Own elaboration.

To analyze their effect on the UHI intensity, we first calculated circle areas with $250 \mathrm{~m}$ radii, because a minimum diameter of 400-1,000 m is required (Stewart \& Oke, 2012) for air at screen height to become adjusted to the underlying surface (Oke, 2004). As a result, the measuring points of each LCZ are in the center of the circles, from which we computed average temperatures for the winter episode.

\section{Results}

We present a sample of local climate zones mapped in Presidente Prudente, from which we analyzed thermal variations in relation to the traverses mean temperatures. We then compared pairwise average temperature differences and UHI intensity defined as $\Delta T_{\text {LCZ X-D }}$. The main characteristics of each LCZ in the city are summarized in table 2.

Table 2. Descriptions of local climatic zones (LCZ) in Presidente Prudente

\begin{tabular}{|c|c|c|}
\hline $\mathbf{L C Z}^{1}$ & Description & Aerial View $^{2}$ \\
\hline $\begin{array}{c}\operatorname{LCZ} 2_{4}-\text { Compact midrise with } \\
\text { open high-rise }\end{array}$ & $\begin{array}{l}\text { Form: Mix of midrise ( } 3 \text { stories tall) and high-rise buildings (tens of stories } \\
\text { tall). Closely spaced buildings separated by narrow streets. Heavy building } \\
\text { materials (concrete, iron, brick, glass) and roofs with cement/ceramic tiles or } \\
\text { metal sheets. Land cover mostly paved with scattered or no trees. Heavy } \\
\text { traffic flow. Function: Residential (apartments); commercial (office } \\
\text { buildings, shops). Location: Core (downtown). }\end{array}$ & \\
\hline Compact low-rise & $\begin{array}{l}\text { Form: Closely spaced buildings } 1-2 \text { stories tall. Small buildings along } \\
\text { narrow strects. Heavy building materials (stone, concrete, brick) and roofs } \\
\text { with asbestos-cement sheets or ceramic tile. Land cover mostly paved with } \\
\text { few or no trees. Moderate to heavy traffic flow. Function: Residential } \\
\text { (single-unit housing); commercial (small shops). Location: Periphery } \\
\text { (western area). }\end{array}$ & \\
\hline LCZ 5 - Open midrise & $\begin{array}{l}\text { Form: Open arrangement of midrise buildings ( } 3 \text { stories tall). Heavy building } \\
\text { materials (concrete, brick, steel, glass). Abundance of pervious land cover } \\
\text { (low plants, scattered trees). Moderate to heavy traffic flow. Function: } \\
\text { Institutional (campuses, schools). Location: West of central- downtown. }\end{array}$ & \\
\hline LCZ 7 - Lightweight low-rise & $\begin{array}{l}\text { Form: Single-story buildings set in a compact arrangement and separated by } \\
\text { narrow streets. Little or no consolidated infrastructure. Lightweight and heavy } \\
\text { building materials (wood, stone, cement, brick), thin walls and roofs with } \\
\text { asbestos-cement sheets, ceramic tile, or metal sheets. Land cover mostly } \\
\text { paved with few or no trees, bare soil, and surrounding vegetated areas (low } \\
\text { plants, scattered trees). Low traffic flow. Function: Residential (low-cost } \\
\text { housing). Location: Periphery (north of central- downtown). }\end{array}$ & \\
\hline LCZ D - Low plants & $\begin{array}{l}\text { Form: Featureless landscape with pervious surface, predominantly low plant } \\
\text { cover. Few or no trees, roads, or buildings. Low or no traffic flow. Function: } \\
\text { Grassland or agriculture (pasture). Location: Surrounding rural area (south of } \\
\text { central- downtown). }\end{array}$ & \\
\hline
\end{tabular}

Source: ${ }^{1}$ LCZ images from Stewart \& Oke (2012); ${ }^{2}$ Google Earth 7.1.5.1557 - eye altitude of $900 \mathrm{~m}$ and circle areas with $250 \mathrm{~m}$ radius. Own elaboration. 
On 30 June and 1 July, the advance of a polar anticyclone through the region cooled air temperatures, as shown by a negative shift $\left(4.3-9.6^{\circ} \mathrm{C}\right)$ from the traverse mean $\left(20.5^{\circ} \mathrm{C}\right)$ (figure 5$)$. With the displacement of the cold air mass over the next days, warming was visible through a positive shift from the winter values.

LCZ D (low plants) had the widest range of temperatures, with an average difference of $-2.4^{\circ} \mathrm{C}$, whereas LCZ 7 (lightweight low-rise) had the lowest thermal difference $\left(-0.2^{\circ} \mathrm{C}\right)$. The largest temperature drops between consecutive zones are $4^{\circ} \mathrm{C}$, from LCZ D to LCZ 7 on 30 June, and $2.1^{\circ} \mathrm{C}$, from LCZ 3 (compact low-rise) to LCZ 5 (open midrise) on 3 July.

In general, thermal differentiation of LCZs in Presidente Prudente did not occur linearly; however, temperature differences dropped gradually from compact built zones at the top, to open and vegetated zones at the bottom-similar to the LCZ hierarchy in Vancouver (Stewart \& Oke, 2010). Further, LCZ 3 (compact low-rise) presented greater positive departures than the other compact built zones, owing to its building morphology and lack of vegetation.

Figure 5. Thermal differentiation of local climate zones using temperatures from mobile traverses in Presidente Prudente during calm and clear evenings, June and July 2014

\section{Departure from traverse mean temperature $\left({ }^{\circ} \mathrm{C}\right)$}

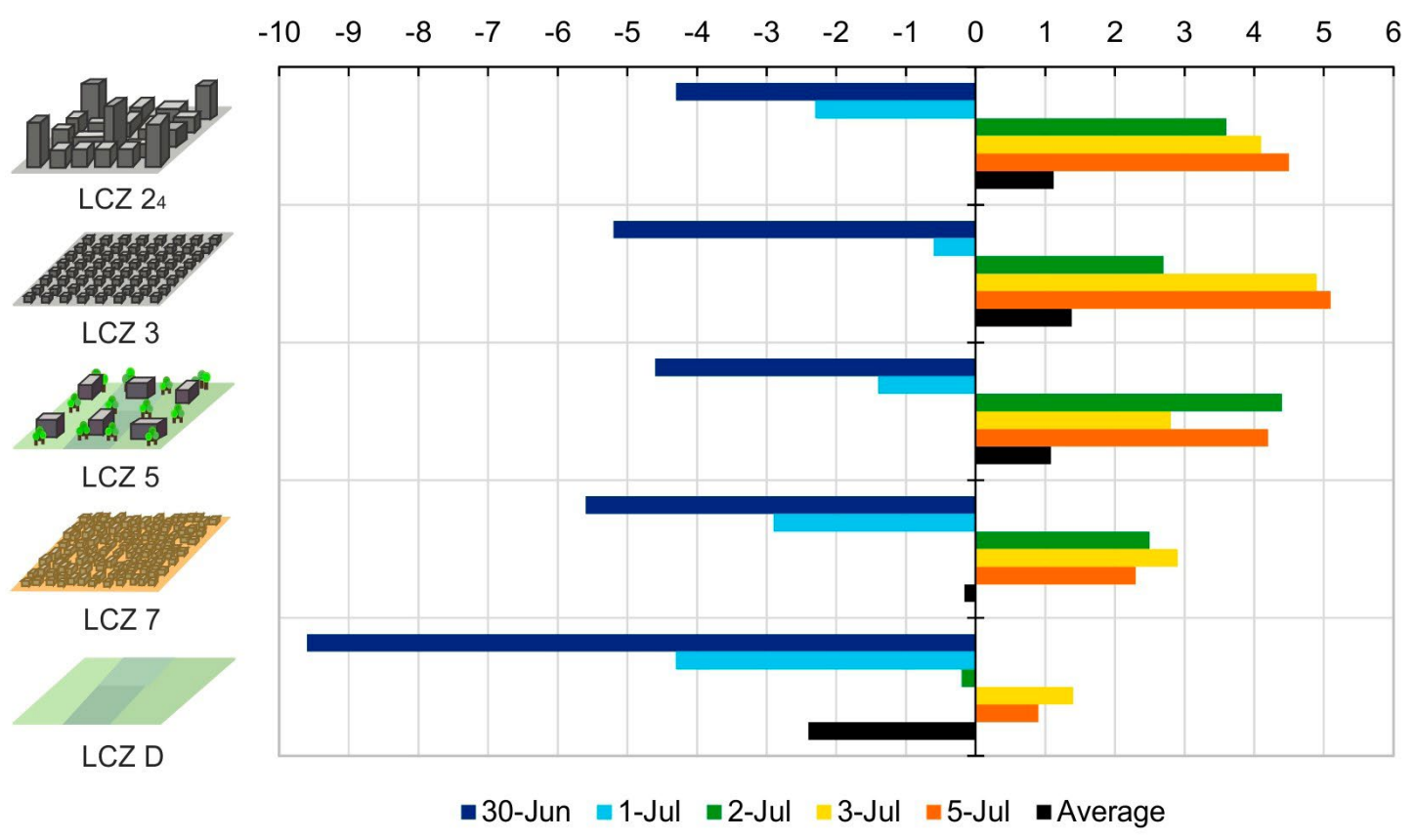

Source: LCZ images from Stewart \& Oke (2012). Own elaboration.

UHI intensity during the winter, defined as $\Delta T_{\mathrm{LCZX} \text {-D }}$, ranged from $2.2^{\circ} \mathrm{C}$ to $3.8^{\circ} \mathrm{C}$, on average, across the selected local climate zones (figure 6). In LCZ $2_{4}$, temperatures are $3.5^{\circ} \mathrm{C}$ higher, on average, than in LCZ D, but daily maximum nighttime UHI intensity in LCZ $2_{4}$ reached $5.3^{\circ} \mathrm{C}$ on June 30.

On the other hand, on individual nights, LCZ 3 presented temperatures between $2.9-4.4^{\circ} \mathrm{C}$ higher than LCZ D, and greater heat island intensity on average $\left(3.8^{\circ} \mathrm{C}\right)$ for the winter period. Temperatures in LCZ 5 (open midrise) are $1.4-5^{\circ} \mathrm{C}$ larger than the natural zone, whereas in LCZ 7 they are $1.4-4^{\circ} \mathrm{C}$ higher.

Based on inter-zone temperature differences, the largest average difference, $\Delta T_{\text {LCZ3-D, }}$ is approximately $4^{\circ} \mathrm{C}$, followed by $\Delta T_{\mathrm{LCZ} 5-\mathrm{D}}$ at $3.5^{\circ} \mathrm{C}$ (table 3), whereas the smallest differences, $\Delta T_{\mathrm{LCZ} 3-24,}$ and $\Delta T_{\mathrm{LCZ} 3-5}$ are $0.3^{\circ} \mathrm{C}$.

Once again, the thermal difference from $\Delta T_{\text {LCZ 3-D }}$ being higher than the differences in $\Delta T_{\text {LCZ 24-D }}$ does not express the expected temperature decrease sequence. However, this pattern can be associated with the physical setting in LCZ 3, where buildings are closely spaced with a more compact arrangement than the other compact zones. As a result, little to no space is left for vegetation cover and its cooling effect. 
Figure 6. Heat island intensity $\left(\Delta T_{\text {LCZ X-D }}\right)$ in Presidente Prudente during nighttime traverses, June-July 2014 (5 nights)

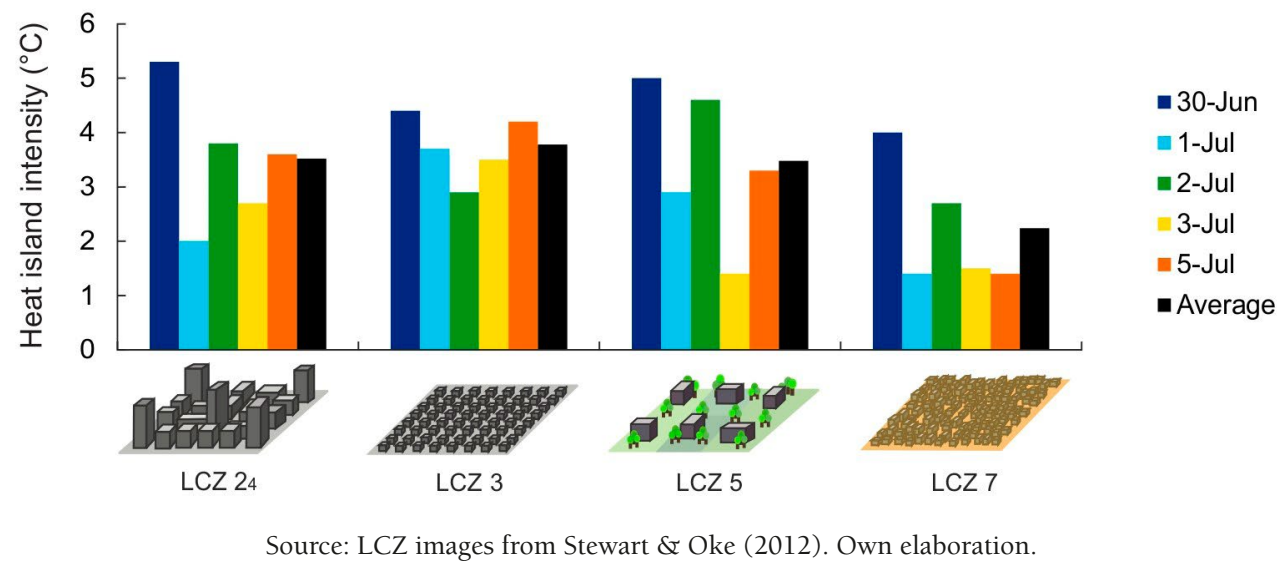

Table 3. Inter-zone thermal differences in Presidente Prudente

\begin{tabular}{|c|c|c|c|c|c|}
\hline LCZ & $\mathbf{2 4}^{4}$ & $\mathbf{3}$ & $\mathbf{5}$ & $\mathbf{7}$ & $\mathbf{D}$ \\
\hline $\mathbf{2 4}$ & 0 & -0.3 & 0 & 1.3 & 3.5 \\
\hline $\mathbf{3}$ & 0.3 & 0 & 0.3 & 1.6 & 3.8 \\
\hline $\mathbf{5}$ & 0 & -0.3 & 0 & 1.3 & 3.5 \\
\hline $\mathbf{7}$ & -1.3 & -1.6 & -1.3 & 0 & 2.2 \\
\hline $\mathbf{D}$ & -3.5 & -3.8 & -3.5 & -2.2 & 0 \\
\hline
\end{tabular}

Own elaboration.

We expected a higher contrast between classes with significant differences in geometry and land cover than between classes with similar physical characteristics (Stewart \& Oke, 2012). Nonetheless, the pairwise $\Delta T_{\mathrm{LCZ} 3-5}$ presented the smallest thermal difference $\left(0.3^{\circ} \mathrm{C}\right)$. This disruption in the pattern can be attributed to anthropogenic heat from moderate to heavy traffic flow in both LCZs, which overrode the regular effects of building morphology and surface cover.

In addition, the fact that UHI intensity depends on the method of reporting is noteworthy, especially when using average temperatures. For instance, no average thermal differences were observed between the compact midrise with high-rise buildings and open midrise zones $\left(\Delta T_{\text {LCZ 24-5 }}\right)$. In contrast, using daily data from the traverses, differences ranged from $0.3^{\circ} \mathrm{C}$ to $1.3^{\circ} \mathrm{C}$.

\section{Discussion}

The urban climate in Presidente Prudente was investigated for more than a decade, and heat islands of different intensities that can reach up to $10^{\circ} \mathrm{C}$ were detected (Amorim, 2000; Amorim, Dubreuil, Quenol $\&$ Sant'Anna Neto, 2009; Barbosa \& Amorim, 2012; Cardoso, 2015). The UHI formation can be associated with the built urban forms in the city, characterized by closely spaced buildings, few or no trees, and building materials that are not appropriate for the region's climate, whereas its intensification also depends on stable weather conditions.

Besides that, the use of information from urban climate studies as a support to urban planning is still incipient in Brazilian cities, where decision makers usually prioritize the economic rather than the social and environmental aspects. "These factors lead to an urban thermal environment that influences the residents' health, especially the low-income population, who are less likely to adapt to climate changes owing to their limited access to cooling facilities." (Cardoso, Dorigon, Teixeira \& Amorim, 2017, p. 2).

Although the lack of use of knowledge about the heat island effects by local government and planners, there is a need to advance UHI investigation since it can exacerbate thermal stress and compromise the population and the quality of life. The greater the awareness of this issue, the greater its insertion in the agenda of decision makers to prevent or mitigate urban heat islands. 
Despite our small dataset - five mobile traverses during winter-, thermal contrasts between zones with large differences in surface morphology and land cover, such as LCZs $2_{4}$ and $\mathrm{D}$, exceed $5^{\circ} \mathrm{C}$ on an individual night and reached $3.5^{\circ} \mathrm{C}$, on average. On the contrary, thermal differences among similar zones, such as LCZs $2_{4}$ and 3 were $<0.5^{\circ} \mathrm{C}$. However, inter-zone temperature differences tend to be underestimated as temperatures were taken over paved roads and across areas accessible to cars (Stewart, Oke $\&$ Krayenhoff, 2014).

Through heat island intensity, defined as $\Delta T_{\text {LCZX-Y }}$, we verified the role of physical settings in rising intraurban temperatures, though open set and vegetation cover were associated with lower temperatures. Although maximum UHI intensities were identified among densely built zones, the effects of anthropogenic heat on increasing temperatures in open arrangements (LCZ 5) were notable.

Overall, the UHI intensities based on inter-zone thermal differences derived here are significant and relate well with previous studies. For instance, Perera, Emmanuel \& Mahanama (2012) investigated heat islands and LCZs in Colombo, Sri Lanka, where UHI intensities ranged from $0.1^{\circ} \mathrm{C}$ to $4.4^{\circ} \mathrm{C}$ over the rural site selected. In Presidente Prudente, the maximum thermal difference between the compact zones and the low plants zone was $3.8^{\circ} \mathrm{C}$.

Stewart, et al. (2014) reported similar results in Nagano, Japan, where temperatures from nighttime traverses in LCZ $2_{4}$ were about $3.5^{\circ} \mathrm{C}$ higher than LCZ D during the cold season. The corresponding $\Delta T$ LCZ 24-D from our traverses was, on average, $3.5^{\circ} \mathrm{C}$. Temperatures in LCZ 5 in Uppsala, Sweden, were $3^{\circ} \mathrm{C}$ higher than in LCZ D, and based on our results, $\triangle T_{\text {LCZ 5-D }}$ reached a maximum difference of $3.5^{\circ} \mathrm{C}$.

Alexander \& Mills (2014) examined UHIs using LCZs in Dublin, Ireland, and we found a similar relation to their findings here with $\Delta T_{\text {LCZ3-D }}$. Our traverses found a $3.8^{\circ} \mathrm{C}$ difference between LCZ 3 and LCZ D, whereas it was $3.1^{\circ} \mathrm{C}$ in Dublin. In Szeged, Hungary, Lelovics et al. (2013) carried out mobile surveys to gather temperatures across LCZs and found a difference of $3.6^{\circ} \mathrm{C}$ between LCZ 3 and LCZ D, which is the closest analogous value compared to ours.

The application of local climate zones to UHI investigations is recent in Brazil, which makes it challenging to establish a direct comparison between our results from selected LCZs and their different UHI intensities. However, considering thermal differences among the warmest and the coolest areas registered during winter in Brazilian cities, there are similar correspondences to our findings in Presidente Prudente.

Using automobile surveys to gather temperatures in Jales, São Paulo, Ugeda Junior (2012) verified the occurrence of heat islands with intensities up to $9^{\circ} \mathrm{C}$, on average, defined by the traditional "urban-rural" classification. Based on this study, we can mention the LCZ D, a featureless landscape with pervious surface and low plant cover that showed a maximum negative shift of $9.6^{\circ} \mathrm{C}$ in relation to the traverse mean temperature.

On the other hand, Ortiz Porangaba (2015) conducted four mobile traverses across Assis, São Paulo, and daily maximum intensities varied from $1.7^{\circ} \mathrm{C}$ to $4.6^{\circ} \mathrm{C}$. The highest temperatures were related to densely built areas, whereas the lowest ones were in rural areas with vegetation cover. Comparing with our results, daily maximum UHI intensities ranged from $3.5^{\circ} \mathrm{C}$ ( $\Delta T_{\text {LCZ 3-D }}$ on July 3 ) to $5.3^{\circ} \mathrm{C}\left(\Delta T_{\text {LCZ 24-D }}\right.$ on June 30) over five nights.

That range at our traverses shows similarity to those reported by Minaki (2014) during a survey along Araçatuba, São Paulo. Maximum intensities varied from $4.7^{\circ} \mathrm{C}$ to $6.4^{\circ} \mathrm{C}$, and areas with high built density and heavy traffic flow presented higher temperatures compared with rural areas. Likewise, for clear nights with wind speed inferior to $1 \mathrm{~m} \mathrm{~s}^{-1}$, Moreira (2016) found temperature differences of approximately $7^{\circ} \mathrm{C}$ in Penápolis, São Paulo, where the lowest temperatures were verified at a vegetated valley bottom.

Those studies in cities with tropical and continental characteristics, including Presidente Prudente, allow us to associate urban morphology and land cover with the formation of UHIs. By assessing the temperature profiles of the cities, the authors verified the role of built density in increasing temperatures, whereas open areas, vegetation cover, and surface relief were related to lower temperatures.

\section{Conclusions}

As a typical Brazilian tropical city, Presidente Prudente presents warmer conditions throughout the year. Together with the complex mix of heterogeneous landscapes, these factors lead to the formation of heat islands that can intensify the thermal discomfort experienced by inhabitants. 
Therefore, UHI investigation is essential to improve the procedures for its observation and communication, advance urban climate studies, and support planning methods. The LCZ scheme by Stewart (2011) provides a practical guide in heat island investigation in different cities, and its application in Presidente Prudente confirmed the existence of intraurban heat islands with different intensities.

Observing temperatures in Presidente Prudente during winter (30 June-5 July 2014) was ideal for studying heat island formation and LCZ differentiation because stable weather conditions maximized local climate differences. Nocturnal temperatures recorded in compact built zones were the highest, followed by open midsize, lightweight low-rise, and low plants zones.

Since the UHI intensity changes on a daily and seasonal basis, we highlight the importance of measurements at hourly intervals for several days or months to analyze the diurnal evolution of heat islands in each LCZ, and in different synoptic conditions. Furthermore, other processes and physical properties need to be added in future works, such as anthropogenic heat flux, turbulent flow, sensible and latent heat flux, thermal conductivity, and heat capacity. LCZs should be tested for these different attributes in an attempt to better describe the urban climate in Presidente Prudente.

As nonlinear interactions and correlations between different aspects of microclimate are numerous, it is not always possible to develop generalized guidelines for an urban planning that considers the cities climate characteristics (Masson, 2000; Huttner, 2012). Thus, field observations along different LCZs should be used together with numerical models to simulate their climate dynamics and assess the impact of urban tropical environments on the microclimate.

In general, the information derived from this study can be integrated with urban planning in order to assist the elaboration of specific mitigation strategies for each local climate zone. Results from Presidente Prudente also provide elements to guide further studies in other tropical cities, and the development of new investigations with this classification system may contribute to strengthen the communication of knowledge and its implications to end-users as local governments and planners.

\section{Acknowledgments}

The authors thank the São Paulo Research Foundation (FAPESP) for the financial support; grant 2013/02057-0.

\section{References}

Abreu, D.S. (1972). Formação histórica de uma cidade pioneira paulista: Presidente Prudente. Presidente Prudente: Faculdade de Filosofia, Ciências e Letras.

Alexandre, M.J.O. (2013). El clima urbano de la ciudad de Natal (Brasil), aplicando modelos de campo y teledetección orbital. Tesis Doctoral, Departamiento de Geografía, Universidad Autonoma de Madrid, $348 \mathrm{pp}$.

Alexander, P.J. \& Mills, G. (2014). Local Climate Classification and Dublin's Urban Heat Island. Atmosphere, (5), 755-774. https://doi.org/10.3390/atmos5040755

Amorim, M.C.C.T. (2000). O clima urbano de Presidente Prudente/SP. Tese (Doutorado em Geografia) Faculdade de Filosofia, Letras e Ciências Humanas, Universidade de São Paulo, São Paulo, 378 pp.

Amorim, M.C.C.T. (2017). Teoria e método para o estudo das ilhas de calor em cidades tropicais de pequeno e médio porte. Tese (Livre Docência) - Faculdade de Ciências e Tecnologia, Universidade Estadual Paulista, Presidente Prudente, 178 pp.

Amorim, M.C.C.T., Dubreuil, V., Quenol, H. \& Sant'Anna Neto, J.L. (2009). Características das ilhas de calor em cidades de porte médio: exemplos de Presidente Prudente (Brasil) e Rennes (França). Confins (Paris), (7), 1-16.

Amorim, M.C.C.T., Dubreuil, V. \& Cardoso, R.S. (2015). Modelagem espacial da ilha de calor urbana em Presidente Prudente (SP) - Brasil. Revista Brasileira de Climatologia, (16), 29-45. http://dx.doi. org/10.5380/abclima.v16i0.40585

Arnfield, A.J. (2003). Two decades of urban climate research: A review of turbulence, exchanges of energy and water, and the urban heat island. Int. J. Climatol., (23), 1-26. https://doi.org/10.1002/joc.859 
Auer, A.H. (1978). Correlation of Land Use and Cover with Meteorological Anomalies. J. Appl. Meteor., (17), 636-643. https://doi.org/10.1175/1520-0450(1978)017<0636:COLUAC >2.0.CO;2

Barbosa, H.P. \& Amorim, M.C.C.T. (2012). Clima urbano em Presidente Prudente/SP: diferenças térmicas e higrométricas urbano/rural em episódios de outono. Revista GeoNorte, (2), 220-232.

Barrios, N.A.Z. \& Sant'anna Neto, J.L. (1996). A circulação atmosférica no extremo oeste paulista. Boletim climatológico, Presidente Prudente, (1), 8-9.

Bechtel, B., Langkamp, T., Böhner, J., Daneke, C., Oßenbrügge, J. \& Schempp, S. (2012). Classification and modelling of urban micro-climates using multisensoral and multitemporal remote sensing data. In International Archives of the Photogrammetry, Remote Sensing and Spatial Information Sciences, Volume XXXIX-B8, 2012 XXII ISPRS Congress, Melbourne, Australia. https://doi.org/10.5194/ isprsarchives-XXXIX-B8-463-2012

Brazilian Institute of Geography and Statistics (IBGE) (2016). População estimada 2016. Retrieved November 23, 2016, from http://cidades.ibge.gov.br/v3/cidades/home-cidades

Cardoso, R.S. (2015). Classificação de potenciais unidades climáticas em Presidente Prudente-SP. Dissertação (Mestrado em Geografia) - Faculdade de Ciências e Tecnologia, Universidade Estadual Paulista, Presidente Prudente, 135 pp.

Cardoso, R.S., Dorigon, L.P., Teixeira, D.C.F \& Amorim, M.C.C.T. (2017). Assessment of Urban Heat Islands in Small- and Mid-Sized Cities in Brazil. Climate, (5), 1-14. https://doi.org/10.3390/cli5010014

Chandler, T.J. (1965). The climate of London. London: Hutchinson.

Collishonn, E. (1998). O campo térmico da Região Metropolitana de Porto Alegre: análise a partir da interação entre as variáveis ambientais na definição do clima urbano. Dissertação (Mestrado) - Universidade Federal de Santa Catarina, Florianópolis, 167 pp.

Collischonn, E. \& Mattos, G.P. (2011). Classificação de ambientes termicamente homogêneos para estudos de clima na camada do dossel urbano - metodologia e aplicação à cidade de Pelotas/RS. Revista Brasileira de Climatologia, (9), 56-67. https://doi.org/10.5380/abclima.v9i0.27515

Dumke, E.M.S. (2007). Clima urbano/conforto térmico e condições de vida na cidade - uma perspectiva a partir do Aglomerado Urbano da Região Metropolitana de Curitiba (AU-RMC). Tese (Doutorado em Meio Ambiente e Desenvolvimento) - Universidade Federal do Paraná, Curitiba, 417 pp.

Ellefsen, R. (1990/91). Mapping and measuring buildings in the urban canopy boundary layer in ten US cities. Energy and Buildings, (15-16), 1025-1049.

Grimmond, S. (2007). Urbanization and global environmental change: local effects of urban warming. Geographical Journal, (173), 83-88. https://doi.org/10.1111/j.1475-4959.2007.232_3.x

Hinkel, K.M., Nelson, F.E., Klene, A.E. \& Bell, J.H. (2003). The urban heat island in winter at Barrow, Alaska. Int. J. Climatol., (23), 1889-1905. https://doi.org/10.1002/joc.971

Huttner, S. (2012). Further development and application of the 3D micro climate simulation ENVI-met. Thesis (Doctor of Science) - Faculty of Chemistry, Pharmacy and Geosciences, Johannes-GutenbergUniversity of Mainz, Mainz, 147 pp.

Leconte, F., Bouyer, J., Claverie, R. \& Pétrissans, M. (2015). Estimation of spatial air temperature distribution at sub-mesoclimatic scale using the LCZ scheme and mobile measurements. In Proceedings of the 9th International Conference on Urban Climate (ICUC9) jointly with 12th Symposium on the Urban Environment, Toulouse, France.

Lelovics, E., Gál, T. \& Unger, J. (2013). Mapping local climate zones with a vector-based GIS method. In Proceedings of the Air and Water Components of the Environment: Conference Dedicated to World Meteorological Day and World Water Day, Cluj-Napoca, Romania.

Lombardo, M.A. (1985). Ilha de Calor nas metrópoles: o exemplo de São Paulo. São Paulo: Hucitec.

Masson, V. (2000). A Physically-Based Scheme for the Urban Energy Budget in Atmospheric Models. Boundary-Layer Meteorology, (94), 357-397. https://doi.org/10.1023/A:1002463829265

Mendonça, F.A. (1994). O clima e o planejamento urbano de cidades de porte médio e pequeno. Proposição metodológica para estudo e sua aplicação à cidade de Londrina/PR. Tese (Doutorado em Geografia Física) - Faculdade de Filosofia, Letras e Ciências Humanas, Universidade de São Paulo, São Paulo. 
Mendonça, F. (2003). Clima e Planejamento urbano em Londrina - proposição metodológica e de intervenção urbana a partir do estudo do campo térmico. In C.A.F. Monteiro \& F. Mendonça (Eds.), Clima urbano (pp. 93-120). São Paulo: Contexto.

Middel, A., Häb, K., Brazel, A.J., Martin, C.A. \& Guhathakurta, S. (2014). Impact of urban form and design on mid-afternoon microclimate in Phoenix Local Climate Zones. Landscape and Urban Planning, (122), 16-28. https://doi.org/10.1016/j.landurbplan.2013.11.004

Minaki, C. (2014). O Clima Urbano Como Indicador de qualidade ambiental: estudo de caso da paisagem urbana de Araçatuba/SP. Tese (Doutorado em Geografia) - Faculdade de Ciências e Tecnologia, Universidade Estadual Paulista, Presidente Prudente, 266 pp.

Monteiro, C.A.F. (1976). Teoria e Clima Urbano. São Paulo: USP.

Moreira, J.L. (2016). O Clima Urbano em Penápolis/SP: Análise da temperatura e umidade intraurbana. Dissertação (Mestrado em Geografia) - Faculdade de Ciências e Tecnologia de Presidente Prudente, Universidade Estadual Paulista, Presidente Prudente, 207 pp.

Oke, T.R. (1987). Boundary Layer Climates (2nd ed.). New York: Methuen.

Oke, T.R. (2004). Initial guidance to obtain representative meteorological observations at urban sites. IOM Rep. 81, WMO/TD-No. 1250, 47 pp. Retrieved from http://www.wmo.int/pages/prog/www/IMOP/ publications/IOM-81/IOM-81-UrbanMetObs.pdf

Ortiz Porangaba, G.F. (2015). O clima urbano das cidades do interior do estado de São Paulo: uma análise do campo térmico de Assis, Cândido Mota, Maracaí e Tarumã. Tese (Doutorado em Geografia) - Faculdade de Ciências e Tecnologia, Universidade Estadual Paulista, Presidente Prudente, 354 pp.

Perera, N.G.R., Emmanuel, R. \& Mahanama, P.K.S. (2012). Mapping “Local Climate Zones” and relative Warming Effects in Colombo, Sri Lanka. In Proceedings of the 8th International Conference on Urban Climate (ICUC8) and 10th Symposium on the Urban Environment, Dublin, Ireland.

Pitton, S.E.C. (1997). As cidades como indicadores de alterações térmicas. Tese (Doutorado em Geografia Física) - Faculdade de Filosofia, Letras e Ciências Humanas, Universidade de São Paulo, 272 pp.

Puliafito, S.E., Bochaca, F.R., Allende, D.G. \& Fernandez, R. (2013). Green Areas and Microscale Thermal Comfort in Arid Environments: A Case Study in Mendoza, Argentina. Atmospheric and Climate Sciences, 3(3), 372-384. https://doi.org/10.4236/acs.2013.33039

Sant'anna Neto, J.L. (Ed.). (2002). Os climas das cidades brasileiras. Presidente Prudente: UDUNESP.

Stewart, I.D. (2011). Redefining the urban heat island. Ph.D. dissertation, Department of Geography, University of British Columbia, 352 pp. Retrieved from https://circle.ubc.ca/handle/2429/38069

Stewart, I.D. \& Oke, T.R. (2010). Thermal differentiation of local climate zones using temperature observations from urban and rural field sites. Extended Abstracts, 9th Symp. on Urban Environment, Keystone, CO, Amer. Meteor. Soc., 1.1. Retrieved from http://ams.confex.com/ams/19Ag19BLT9Urban/webprogram/ Paper173127.html

Stewart, I.D. \& Oke, T.R. (2012). Local Climate Zones for Urban Temperature Studies. Bull. Amer. Meteor. Soc., (93), 1879-1900. https://doi.org/10.1175/BAMS-D-11-00019.1

Stewart, I.D., Oke, T.R. \& Krayenhoff, E.S. (2014). Evaluation of the 'local climate zone' scheme using temperature observations and model simulations. Int. J. Climatol., (34), 1062-1080. https://doi. org/10.1002/joc.3746

Tarifa, J.R. (1977). Análise comparativa da temperatura e umidade na área urbana e rural de São José dos Campos (SP). Geografia, (4), 59-80.

Ugeda Junior, J.C. (2012). Clima urbano e planejamento na cidade de Jales-SP. Tese (Doutorado em Geografia) - Faculdade de Ciências e Tecnologia, Universidade Estadual Paulista, Presidente Prudente, $383 \mathrm{pp}$.

Voogt, J.A. (2004). Urban Heat Islands: Hotter Cities. Retrieved July 15, 2016, from http://www. actionbioscience.org/environment/voogt.html 